\title{
EFEK KONSENTRASI DAN LAMA PERENDAMAN DALAM LARUTAN URINE SAPI TERHADAP PERTUMBUHAN SETEK MAWAR
}

\author{
Oleh: \\ Sri Nur Widyastuti L.*) \\ Fajar Bachtiar Mulyana**) \\ Farida Iriani**) \\ Email coresponden: farida.iriani52@gmail.com
}

\begin{abstract}
ABSTRAK
Mawar adalah kelompok florikultura yang dimanfaatkan sebagai tanaman hias halaman, tanaman dalam pot, bunga tabur, bunga potong, bahan baku kosmetika dan obatobatan. Permintaan bunga potong mawar terus meningkat dari tahun ke tahun, baik internasional maupun domestik, sehingga teknik perbanyakan tanaman mawar dalam waktu singkat, perlu diteliti. Percobaan telah dilaksanakan pada bulan Agustus sampai September 2020 di Kampung Ciburial Desa Cibogo Kec. Lembang Kab. Bandung Barat, Prov. Jawa Barat dengan ketinggian tempat 1.214 mdpl. Percobaan menggunakan metode Rancangan Acak Kelompok (RAK) dua faktor, yaitu konsentrasi urine sapi dan lama perendaman dengan masing-masing faktor perlakuan terdiri atas tiga taraf. Terdapat sembilan kombinasi perlakuan, dan setiap perlakuan diulang sebanyak empat kali. Jenis perlakuan faktor pertama, yaitu $\mathrm{k}_{1}\left(10 \mathrm{mlL}^{-1}\right), \mathrm{k}_{2}\left(20 \mathrm{mLL}^{-1}\right)$, dan $\mathrm{k}_{3}\left(30 \mathrm{mlL}^{-1}\right)$, sedangkan faktor kedua, yaitu $\mathrm{l}_{1}(30$ menit), $l_{2}$ (45 menit), dan $l_{3}(60$ menit). Variabel respon yang diamati adalah panjang tunas, jumlah tunas, jumlah daun, panjang daun, luas daun, panjang akar, dan volume akar. Tidak terjadi interaksi antara konsentrasi dan lama perendaman dalam urine sapi terhadap pertumbuhan setek batang mawar varietas first red. Berdasarkan hasil sidik ragam, setek mawar yang direndam selama 45 menit dalam larutan yang mengandung urine sapi, adalah memberi efek terbaik terhadap variabel respon panjang tunas dan volume akar.
\end{abstract}

Kata kunci : Urine sapi, Konsentrasi, Lama perendaman, Setek mawar.

\section{ABSTRACT}

Roses of floriculture group that used as ornamental garden plants, potted plants, sow flowers, cut flowers, raw material for cosmetics and medicines. The demand for cut roses contimues to increase from year to year, both internationally and dosmetically, so the technique of propagation of roses in a short time needs to be researched. The experiment was carried out from August to September 2020 in Kampung Ciburial, Desa Cibogo, Lembang, Bandung Barat, Jawa Barat provinsi with an altitude of 1,214 meters above sea level. The experiment used two-factor Randomized Block Design method, namely the concentration of cow's urine and duration immersion with each treatment factor consisting of three levels. There werw nine treatment combinations, and each treatment was repeated four times. The type of treatment of the first factor, namely $k_{1}\left(10 \mathrm{mLL}^{-1}\right), k_{2}\left(20 \mathrm{mlL} \mathrm{L}^{-1}\right)$, and $k_{3}\left(30 \mathrm{mlL} \mathrm{L}^{-1}\right)$, while the second factor, namely $l_{1}$ (30 minutes), $l_{2}$ (45 minute), and $l_{3}$ (60 minute). The response variables observed were shoot length, number of shoots, number of leaves, leaf length, and root volume. There was no interaction between concentration and duration of immersion in cow's urine on the growth of rose stem cuttings of the first red variety. Based on the results of the variance rose cuttins soaked for 45 minutes in a solution containing cow's urine gave the best effect on the response variabels of shoot length and root volume.

Keywords: Cow's urine, Concentration, Soaking time, Rose cutting.

*) Dosen Prodi Agroteknologi Fakultas Pertanian, Universitas Insan Cendekia Mandir.

**) Alumni Prodi Agroteknologi Fakultas Pertanian, Universitas Insan Cendekia Mandir. 


\section{PENDAHULUAN}

Mawar (Rossa bybrida L.), salah satu florikultura dari famili Rosaceae dengan permintaan yang tinggi sepanjang tahun, baik domestik maupun internasional (Rukmana, 2017). Mawar dimanfaatkan sebagai tanaman hias halaman, tanaman dalam pot, bunga tabur, bunga potong untuk rangkaian dekoratif, minuman penyegar, bahan baku kosmetika, dan obat-obatan.

Tanaman mawar umumnya dikembangbiakkan secara vegetatif, sedangkan perbanyakan generatif melalui benih hanya untuk tujuan pemuliaan. Keberhasilan perbanyakan vegetatif melalui setek batang berkayu adalah lebih efektif dibandingkan dengan cara okulasi, cangkok, atau perundukan karena teknik setek relatif lebih mudah, murah, dan membutuhkan waktu lebih singkat (Gunawan, 2014). Namun, ada beberapa kelemahan perbanyakan setek batang, yaitu tidak terbentuk akar tunggang, penyerapan air dan linarut oleh akar tidak maksimal, tidak banyak terbentuk cabang, dan mudah roboh ketika tertiup angin kencang (Ashari, 2006).

Berbagai upaya dapat kita lakukan untuk menyiapkan keberhasilan setek, terutama bagi bahan setek asal batang tua, antara lain dengan mengaplikasikan zat pengatur tumbuh ke media setek agar mampu berperan sebagai stimulan bagi terbentuknya primordia akar dan daun. Telah diketahui bahwa zat pengatur tumbuh, ada yang berasal dari bahan alam, dan ada pula zat pengatur tumbuh yang dibuat secara sintetis. Aplikasi zat pengatur tumbuh sintetis relatif mahal, sedangkan pemanfaatan bahan alam sebagai sumber zat pengatur tumbuh relatif murah dan mudah diperoleh, misalnya bawang merah (Muswita, 2011), air kelapa (Tuhuteru et. al., 2012), dan urine sapi (Lusiana et. al., 2012). Berdasarkan hasil penelitian Yunita (2011), urine sapi merupakan limbah ternak yang mengandung auksin-a (auxentriollic acid), dan auksin-b. Sedangkan Gunawan et. al. (2018), melaporkan bahwa urine sapi mengandung senyawa organik serupa IAA dengan aroma khas yang dapat mencegah datangnya hama, serta berpengaruh positif terhadap pertumbuhan vegetatif tanaman. Berdasarkan hasil uji laboratorium terhadap urine sapi yang digunakan dalam percobaan ini, diperoleh informasi bahwa urine sapi mengandung zat pengatur tumbuh auksin sejumlah 26,72 ppm.mlL ${ }^{-1}$ (dokumen penulis, 2020).

Hasil penelitian Mappanganro et. al. (2010) pada tanaman stroberi yang disiram dengan urine sapi takaran $50 \mathrm{mlL}^{-1} \cdot \operatorname{tanaman}^{-1}$, menunjukkan produksi terbaik dibandingkan dengan takaran lainnya. Pratiwi et. al. (2017) melaporkan bahwa takaran $30 \mathrm{mlL}^{-1}$ urine sapi yang diaplikasikan pada setek tebu, ternyata mampu menstimulasi kecepatan muncul tunas, panjang tunas, jumlah daun, panjang akar, jumlah akar, dan bobot kering per tanaman. Ditambahkannya pula bahwa, urine sapi yang telah difermentasi menjadi pupuk organik cair (biourine), terdeteksi mengandung beberapa unsur hara makro dan mikro, senyawa organik IAA, dan zat pengatur tumbuh sitokinin.

Budiharjo et.al. (2003) melaporkan hasil percobaan mereka atas pencelupan bahan setek anggur dalam larutan urine sapi konsentrasi $20 \%$, ternyata memberi efek 
optimal terhadap panjang tunas, jumlah tunas, jumlah daun, dan jumlah akar. Sedangkan Karimah et.al. (2013) melaporkan bahwa rimpang temulawak jika sebelum tanam direndam dalam air kelapa konsentrasi $50 \%$ atau direndam dalam urine sapi konsentrasi 25\% adalah memberi efek positif yang sama terhadap kemampuan bertunas rimpang temulawak tersebut.

Aplikasi siram urine sapi dalam bentuk pupuk organik cair konsentrasi $40 \%$ memberikan hasil terbaik terhadap variabel respon jumlah bunga.tanaman ${ }^{-1}$, jumlah buah.tanaman ${ }^{-1}$, bobot buah.tanaman ${ }^{-1}$, panjang buah, diameter buah, bobot buah.hektar ${ }^{-1}$, dan kadar air buah tanaman mentimun (Setiaji, 2013). Demikian juga Filaprasetyowati et.al. (2015) melaporkan hasil penelitian mereka atas aplikasi biourine sapi 150 mL.tanaman ${ }^{-1}$ bahwa perlakuan tersebut memberi efek baik terhadap rerata bobot segar konsumsi per tanaman, dan diikuti produksi ton.ha ${ }^{-1}$ tanaman bawang daun, bahkan data tersebut tidak berbeda efeknya dengan produksi bawang daun yang diberi perlakuan pupuk anorganik urea $300 \mathrm{~kg}^{-1}$ + ZA $600 \mathrm{~kg} \cdot \mathrm{ha}^{-1}$. Lama perendaman bahan setek di dalam larutan perendam sesaat sebelum setek ditanam, akan mempengaruhi proses difusi masuknya air dan linarut kedalam dasar setek, sehingga akan mengoptimalkan terbentuknya tunas dan akar (Gunawan, 2014). Hasil penelitian Tuhuteru et. al. (2012) pada setek tanaman buah naga merah yang direndam dalam air kelapa selama 2 jam, berpengaruh terhadap peningkatan tinggi tunas sebesar 7\% dibandingkan tanpa direndam dalam air kelapa. Lusiana et. al., (2012), melaporkan hasil penelitian mereka terhadap setek tanaman sirih merah, yaitu lama perendaman 45 menit dalam urine sapi konsentrasi $300 \mathrm{mlL}^{-1}$ sebelum setek ditanam, menghasilkan pertumbuhan tunas yang lebih baik daripada perlakuan lama perendaman lainnya. Supriyanto et. al. (2014) menginformasikan hasil penelitian mereka, bahwa aplikasi urine sapi konsentrasi $150 \mathrm{mlL}^{-1}$ dengan lama perendaman 60 menit, berpengaruh positif terhadap pertumbuhan semai tanaman jati jenis jabon merah, sehingga rata-rata mampu menambah tinggi tanaman sebesar $8 \%$ dibandingkan perendaman dalam air saja.

Bagaimana efek perlakuan beberapa taraf konsentrasi dalam larutan yang mengandung urine sapi dengan beberapa taraf lama perendaman dalam larutan tersebut terhadap daya bertunas dan pertumbuhan akar setek mawar kultivar first red merupakan tujuan akhir dari penelitian ini. Hasil penelitian diharapkan akan diperoleh informasi tentang manfaat limbah urine sapi, terutama yang berkenaan dengan peran zat pengatur tumbuh alami terhadap keberhasilan perbanyakan vegetatif, khususnya bagi bahan setek batang berkayu keras.

\section{METODE PENELITIAN}

Penelitian telah dilaksanakan dalam rumah kaca (green house) berbahan plastik di area kebun percobaan desa Cibogo, Kecamatan Lembang, Kabupaten Bandung Barat, Prov. Jawa Barat, pada ketinggian tempat $1.214 \mathrm{~m}$ dpl, dan berlangsung pada bulan Agustus sampai dengan September 2020. Suhu rata-rata harian adalah 20-25 
${ }^{\circ} \mathrm{C}$, kelembaban udara berkisar 32-95\% serta rata-rata curah hujan 2.208 mm.tahun ${ }^{-1}$ (Monografi Desa Cibogo, 2020).

Bahan setek batang yang digunakan berasal dari tanaman mawar varietas first red dengan bunga berwarna merah, berasal dari tanaman induk yang sehat, cabangcabang produktif berbunga, berkayu cukup keras dengan diameter kurang lebih $1 \mathrm{~cm}$, dan panjang setek batang mawar $20 \mathrm{~cm}$. Urine sapi yang digunakan berasal dari sapi lokal, dewasa, berkelamin jantan, dan dalam keadaan sehat. Urine sapi terpilih tersebut, ditampung pada pagi hari. Media tanam berupa sekam padi mentah yang telah mengalami proses pelapukan selama kurang lebih enam bulan.

Penelitian menggunakan metode Rancangan Acak Kelompok (RAK) berpola faktorial, terdiri atas dua faktor, menurut prosedur Gomez dan Gomez (1995) kemudian dilanjutkan dengan uji Jarak berganda Duncan pada taraf kepercayaan 95\%. Faktor pertama adalah konsentrasi urine sapi (K), dan faktor kedua adalah lama perendaman (L), serta masing-masing faktor perlakuan terdiri atas tiga taraf.

Faktor pertama $(K)$ terdiri atas tiga taraf, yaitu $\mathrm{k}_{1}\left(10 \mathrm{mlL}^{-1}\right), \mathrm{k}_{2}\left(20 \mathrm{mlL}^{-1}\right)$, dan $\mathrm{k}_{3}\left(30 \mathrm{mlL}^{-1}\right)$. Faktor kedua terdiri atas tiga taraf, yaitu $\mathrm{l}_{1}$ (30 menit), $1_{2}$ (45 menit), dan $1_{3}$ (60 menit). Dengan demikian terdapat sembilan kombinasi perlakuan, dan setiap perlakuan diulang sebanyak empat kali, total media tanam yang berisi $2 \mathrm{~kg}$ sekam mentah adalah 36 polybag, dan setiap polybag ditanam sebanyak dua setek, sehingga dibutuhkan sebanyak 72 bahan setek batang mawar varietas first red dalam ukuran dan kondisi fisik yang relatif seragam.

Variabel respon yang diamati adalah panjang tunas, jumlah tunas, jumlah daun, panjang daun, luas daun, panjang akar, dan volume akar dari setiap tanaman yang dipilih secara acak sebagai sampel. Semua variabel respon yang diamati dilakukan pada hari ke 28 setelah tanam (28 hst).

\section{HASIL DAN PEMBAHASAN}

Selama percobaan berlangsung, tidak ada serangan organisme pengganggu tanaman yang berarti. Gangguan hanya berupa gulma yang tumbuh di dalam polybag bersama-sama dengan setek mawar, terutama gulma dari jenis teki ladang (Cyperus rotundus) dan babadotan (Ageratum conyzoides). Pengendalian dilakukan secara manual dengan menggunakan tangan setiap satu minggu sekali.

Hasil sidik ragam menunjukkan, bahwa tidak terjadi interaksi antara perlakuan taraf konsentrasi urine sapi dan perlakuan taraf lama perendaman terhadap tujuh variabel respon pertumbuhan setek mawar yang diamati, tetapi diperoleh perbedaan efek bermakna akibat perlakuan lama perendaman untuk variabel respon panjang tunas dan volume akar sebagaimana yang disajikan pada Tabel 1. dan Tabel 2. 
Tabel 1. Efek konsentrasi dan lama perendaman dalam urine sapi terhadap panjang tunas setek mawar pada hari ke 28 setelah tanam.

\begin{tabular}{ccl}
\hline Perlakuan & Panjang tunas & $\mathbf{2 8}$ hst $\mathbf{( c m})$ \\
\hline Konsentrasi Urine Sapi & & \\
$\mathrm{k}_{1}\left(10 \mathrm{~mL}^{-1}\right)$ & 3,21 & $\mathrm{a}$ \\
$\mathrm{k}_{2}\left(20 \mathrm{ml}^{-1}\right)$ & 2,94 & $\mathrm{a}$ \\
$\mathrm{k}_{3}\left(30 \mathrm{mlL}^{-1}\right)$ & 2,62 & $\mathrm{a}$ \\
\hline Lama Perendaman & & \\
\hline $\mathrm{l}_{1}(30$ menit $)$ & 2,40 & $\mathrm{x}$ \\
$\mathrm{l}_{2}(45$ menit $)$ & 3,60 & $\mathrm{y}$ \\
$\mathrm{l}_{3}(60$ menit $)$ & 2,77 & $\mathrm{x}$ \\
\hline
\end{tabular}

Keterangan : Nilai rata-rata diikuti dengan huruf yang sama dalam satu kolom berarti tidak berbeda nyata menurut uji Jarak berganda Duncan taraf 5\%.

Tabel 2. Efek konsentrasi dan lama perendaman dalam urine sapi terhadap volume akar setek mawar pada hari ke 28 setelah tanam.

\begin{tabular}{ccc}
\hline Perlakuan & Volume akar & $\mathbf{2 8}$ hst (mL) \\
\hline Konsentrasi Urine Sapi & & \\
$\mathrm{k}_{1}\left(10 \mathrm{mLL}^{-1}\right)$ & 16,67 & $\mathrm{a}$ \\
$\mathrm{k}_{2}\left(20 \mathrm{mlL}^{-1}\right)$ & 19,58 & $\mathrm{a}$ \\
$\mathrm{k}_{3}\left(30 \mathrm{~mL}^{-1}\right)$ & 14,58 & $\mathrm{a}$ \\
\hline Lama Perendaman & & \\
\hline $\mathrm{l}_{1}(30$ menit & 12,08 & $\mathrm{x}$ \\
$\mathrm{l}_{2}(45$ menit $)$ & 25,00 & $\mathrm{y}$ \\
$\mathrm{l}_{3}(60$ menit $)$ & 13,75 & $\mathrm{x}$ \\
\hline
\end{tabular}

Keterangan: Nilai rata-rata diikuti dengan huruf yang sama dalam satu kolom berarti tidak berbeda nyata menurut uji Jarak berganda Duncan taraf 5\%.

Perlakuan lama perendaman 45 menit $\left(1_{2}\right)$ memberi efek positif terhadap pertumbuhan panjang tunas, dan volume akar, artinya 45 menit merupakan waktu optimal bagi dasar setek mawar untuk mengabsorpsi air dan linarut yang terdapat di dalam urine sapi yang digunakan dalam percobaan ini, yaitu auksin dengan kadar 26,72 $\mathrm{ppmL}^{-1}$ (hasil uji laboratorium penulis dengan alat spektrofotometer). Pertumbuhan tunas yang lebih cepat, diduga karena dipengaruhi oleh pertumbuhan akar yang sehat, aktif mengabsorpsi linarut kemudian mengtranslokasikan ke bagian primordia tunas, terbukti hasil sidik ragam menunjukkan bahwa panjang tunas bersinergi dengan variabel respon volume akar.

Lakitan (2015) menyatakan bahwa air diserap oleh bahan setek melalui proses difusi, dipengaruhi oleh tingkat permeabilitas membran sel dan perbedaan potensial air di dalam dan di luar sel. Difusi air akan meningkatkan tekanan turgor di dalam sel, sehingga air lancar masuk ke dalam vakuola, selanjutnya akan mengatur proses pembelahan dan perkembangan sel. Air bersama linarut kemudian akan diangkut kebagian atas tanaman, melalui pembuluh xilem. Pembuluh xilem pada akar, batang, dan daun merupakan suatu sistem berkesinambungan yang saling mempengaruhi satu sama lain. Pertambahan panjang tunas merupakan hasil dari perkembangan sel yang 
bergantung atas suplai air dan unsur hara terlarut, kemudian ditransfer oleh bagian akar ke bagian atas tanaman untuk kegiatan metabolisme, misalnya fotosintesis.

Menurut Hartmann et. al. (1997), pemberian auksin eksogen dapat meningkatkan aktivitas auksin indogen yang telah ada di dalam bahan setek, sehingga pada kadar optimum akan menstimulasi pembelahan dan perkembangan sel, berupa tumbuh tunas dan akar. Dengan demikian, perendaman bahan setek mawar dalam larutan urine sapi pada berbagai taraf konsentrasi sebagaimana dalam percobaan ini, dipastikan telah berhasil mengabsorpsi auksin eksogen dalam waktu 45 menit, sehingga berhasil menstimulasi kecepatan muncul tunas dan menambah biomasa akar, tetapi tidak berhasil untuk memacu perkembangan selanjutnya dari organ-organ yang telah tumbuh, seperti yang diwakili oleh variabel respon luas daun, dan panjang akar.

Efek positif akibat perlakuan lama perendaman 45 menit dalam larutan urine sapi sebelum setek mawar ditanam, juga diperoleh data yang senada dengan data sebagaimana yang disajikan dalam Tabel 1 dan Tabel 2 untuk variabel respon jumlah tunas dan panjang daun, meskipun kedua data variabel respon tersebut tidak bermakna menurut uji jarak berganda Duncan pada taraf kepercayaan 95\% dan jika disajikan dalam bentuk diagram batang, diperoleh seperti pada Gambar 1.

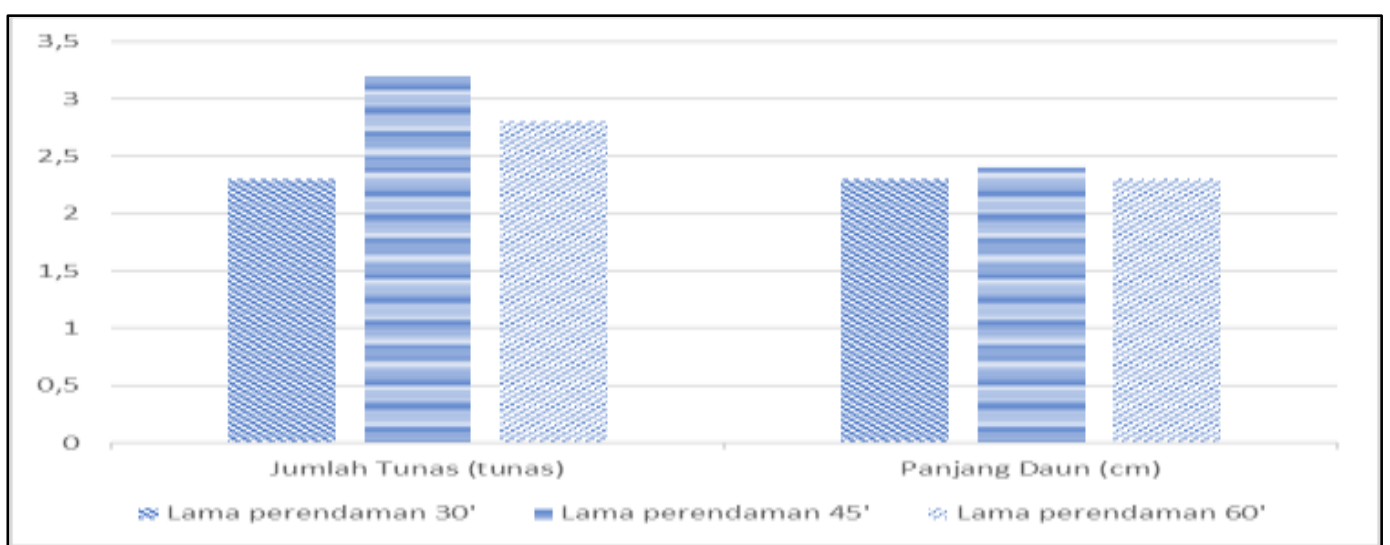

Gambar 1. Efek lama perendaman 45 menit dalam larutan urine sapi terhadap jumlah tunas dan panjang daun setek mawar pada hari ke 28 setelah tanam.

Menurut Zhang et. al. (2013) bahwa kemampuan pembentukan akar setek dipengaruhi oleh berapa besar kandungan karbohidrat dan keseimbangan zat pengatur tumbuh (khususnya auksin) yang tercermin dalam nisbah $\mathrm{C} / \mathrm{N}$ ratio. Nisbah $\mathrm{C} / \mathrm{N}$ ratio bahan setek mawar (Rosa multiflora) terbaik untuk pertumbuhan akar adalah 12:1 (Hambrick et. al., 1991), namun dalam percobaan ini tidak diuji kadar C/N rasio bahan setek sebelum tanam. Dikemukakan oleh Oxlade (2010) bahwa salah satu faktor yang menunjang pertumbuhan adalah unsur hara. Apabila unsur hara tersedia dalam jumlah cukup dari media tanam, maka pertumbuhan dan perkembangan tanaman akan berjalan dengan lancar. Dengan demikian, media tanam sekam mentah yang digunakan dalam percobaan ini, tidak mampu menyediakan unsur makro dan 
unsur mikro dalam bentuk tersedia dan jumlah cukup sesuai kadar yang dibutuhkan untuk proses perkembangan daun dan akar.

Lusiana et. al. (2012) melaporkan bahwa selain auksin, di dalam urine sapi juga terdapat sitokinin yang juga mampu menstimulasi pembentukan daun pada setek. Apabila urine sapi diaplikasikan pada dasar setek dalam konsentrasi optimum, maka tunas akan lebih cepat terbentuk, sehingga dihasilkan jumlah daun lebih banyak. Semakin banyak jumlah tunas, seyogianya akan diikuti oleh banyaknya jumlah daun, karena tunas adalah bakal tangkai daun yang terbentuk di setiap nodus, sehingga perkembangan tunas yang baik akan berbanding lurus dengan jumlah daun yang muncul. Namun hasil percobaan ini menunjukkan bahwa variabel respon panjang tunas tidak diikuti oleh variabel jumlah daun, hal ini dikarenakan penyediaan bahan setek hanya mengukur panjang setek saja tetapi tidak memperhitungkan jumlah nodus yang merupakan bakal primordia tunas dan daun.

Selama pertumbuhan fase vegetatif, daun akan aktif berfotosintesis dan membutuhkan unsur hara $\mathrm{N}$ dalam jumlah cukup dari media tanam, diduga media tanam yang hanya terdiri atas sekam mentah, tidak mengandung unsur $\mathrm{N}$ tersedia dalam jumlah cukup. Sedangkan menurut Hadiswito (2012), bahwa unsur N yang terkandung dalam urine sapi merupakan unsur yang mudah lepas jika tercuci, tetapi jika terikat dapat turut membantu menyerap unsur $\mathrm{P}$ tersedia dari media tanam. Penggunaan media tanam berupa hanya sekam mentah dalam percobaan ini, didasari atas pendapat Perwitasari et. al. (2012) bahwa sekam mentah bersifat tidak mudah lapuk, tinggi unsur kalium $(K)$ yang dibutuhkan tanaman, dan tidak mudah menggumpal atau memadat saat kondisi sekam kering atau basah, sehingga akar tumbuh dengan leluasa. Akar yang tumbuh dari dasar setek, disebut akar adventif, tumbuh dari jaringan kalus dan primordia akar, di daerah kambium vaskuler.

Menurut Wiraatmaja (2017), bahwa terdapat peran salah satu senyawa organik yang dapat membantu mempercepat proses pertumbuhan dan perkembangan akar adventif, yaitu auksin. Dengan demikian perendaman dasar setek selama 45 menit dalam larutan urine sapi sebelum tanam, merupakan waktu optimum bagi proses absorpsi auksin eksogen yang dibutuhkan untuk menstimulasi pertumbuhan akar adventif. Selain itu Hadi (2020) menyarankan bahwa sebaiknya biourine diaplikasikan setiap 7-10 hari sekali, sementara dalam percobaan ini urine sapi hanya diaplikasikan satu kali saja, yaitu sebelum setek ditanam sehingga informasi signifikansi yang diperoleh sebagai efek dari aplikasi urine sapi hanya mengenai kecepatan tumbuh tunas dan biomasa akar saja, yaitu diwakili oleh variabel respon panjang tunas dan volume akar. Balai Pengkajian Teknologi Pertanian Kepulauan Riau (2020) mengungkapkan data, bahwa urine sapi segar mengandung hara yang masih rendah, dan ada unsur patogen bagi tanaman. Karena itu disarankan urine digunakan setelah dilakukan fermentasi terlebih dahulu selama 14-15 hari dengan penambahan senyawa organik tertentu sehingga menjadi larutan yang umum disebut biourine, tujuannya adalah untuk menurunkan kandungan amoniak dan unsur patogen. 
Hasil penelitian Nuraini dan Asgianingrum (2017), menginformasikan bahwa urine sapi yang difermentasi dengan penambahan pupuk hayati tertentu, dapat meningkatkan $\mathrm{N}$-total senilai $860 \%$, bahan organik $282 \%$, dan populasi mikroba sebesar $1.229 \%$. Sedangkan dalam percobaan ini, urine sapi yang digunakan dalam kondisi segar, tidak difermentasikan terlebih dahulu, melainkan langsung dilarutkan dalam air bebas ion, sehingga dipastikan tidak menyediakan unsur hara yang cukup ke media tanam, akibatnya tidak memacu perkembangan lanjut dari organ-organ tunas dan akar yang telah tumbuh. Hal lain yang mempengaruhi keberhasilan tumbuh tunas dan akar dalam percobaan ini, antara lain faktor lingkungan terutama suhu dan kelembaban udara. Saat percobaan berlangsung suhu rata-rata harian cukup rendah dan stabil, sesuai dengan syarat tumbuh yang dibutuhkan oleh setek. Selain itu, kelembaban udara dalam rumah kaca terjaga stabil, serta kelembaban media relatif tinggi karena penyiraman terkontrol, sehingga mempengaruhi terbentuknya jaringan kalus, sebagaimana data yang diwakili oleh variabel respon volume akar.

\section{PENUTUP}

\section{Kesimpulan}

Perlakuan perendaman setek mawar sebelum tanam dalam air bebas ion yang mengandung urine sapi sebagai senyawa terlarut, berapa pun konsentrasinya dengan lama perendaman 45 menit, berpengaruh lebih baik terhadap variabel respon panjang tunas dan volume akar.

\section{Saran}

Lama perendaman 45 menit merupakan waktu optimum untuk digunakan pada percobaan berikutnya dengan konsentrasi urine sapi lebih dari $30 \mathrm{mlL}^{-1}$ atau urine sapi difermentasikan terlebih dahulu sebelum diaplikasikan.

\section{UCAPAN TERIMA KASIH}

Ucapan terima kasih disampaikan kepada yang terhormat Ketua Program Studi Agroteknologi, Dekan, segenap staf Laboratorium Terpadu Fakultas Pertanian Universitas Insan Cendekia Mandiri, dan semua pihak yang sudah berpartisipasi selama pelaksanaan penelitian hingga penyelesaian artikel ilmiah ini disusun.

\section{DAFTAR PUSTAKA}

Ashari, S. (2006). Hortikultura Aspek Budidaya. Universitas Indonesia Press : Jakarta. 490 hal. ISBN: 9794561495

Balai Pengkajian Teknologi Pertanian Kepulauan Riau. (2020). Terapan penggunaan teknologi pemanfaatan bio-urine sapi. BPTP Kepri. Technology-Indonesia.com. Jakarta. Diakses 29 Juni 2020. 
Dokumen Penulis. (2020). Hasil uji laboratorium urine sapi segar dengan alat spektrofotometer. Laboratorim instrumen, Fakultas Pertanian, Universitas Padjadajaran. Agustus, 2020.

Filaprasetyowati, M. Santosa, dan N. Herlina. (2015). Kajian Penggunaan Pupuk Biourin Sapi dan Pupuk Anorganik terhadap Pertumbuhan dan Hasil Tanaman Bawang Daun (Allium fistulosum L.). Jurnal Produksi Tanaman. Fakultas Pertanian, Universitas Brawijaya. 3(3): 239 - 248.

Gomez, A.K., dan Gomez, A.A. (1995). Prosedur Statistik untuk Penelitian Pertanian. Universtas Indonesia Press. 698 hal.

Gunawan, E. (2014). Perbanyakan Tanaman, Cangkok, Setek, Okulasi, Sambung, dan Biji. Penerbit PT Agromedia Pustaka: Jakarta.

Gunawan, B., Pratiwi, Y. I., \& Saadah, T. T. (2018). Study Of Liquid Organic Fertilizer Tech Nano In The Rate Of Increase In Growth Beginning Cuttings Bagal Plant Cane Ps-881. Jurnal Hasil Penelitian: 2 (01).

Hadi, S.N. (2020). Pemanfaatan Urin Sapi sebagai Pupuk Cair (Biourin). Balai Pengkajian Teknologi Pertanian (BPTP) Kalimantan Selatan.

Hadiswito, S. (2012). Membuat Pupuk Organik Cair. Agro Media Pustaka, Jakarta.

Hambrick, C.E, Davies, F.T.Jr., dan Perberton, H.B. (1991). Seasonal Changes in Carbohydarate/Nitrogen Levels During Field Rooting of Rosa multiflora 'Brooks 56' Hardwood Cuttings. Scientia Horticultural. (46): 137-146.

Hartmann, H.T., D.E. Kester, F.T. Davies, dan R.L. Geneve. (1997). Plant Propagation Principles and Practice. Englewood Cliffs, New Jersey: Prentice Hall.

Karimah, A., Purwanti, S. dan Rogomulyo, R. (2013). Kajian Perendaman Rimpang Temulawak (Curcuma xhantorriza Roxb) dalam Urin Sapi dan Air Kelapa untuk Mempercepat Pertunasan. J.Vegetalike 2(2): 1-6.

Lakitan, B. (2015). Dasar-Dasar Fisiologi Tumbuhan. Raja Grafindo Persada, Jakarta.

Lusiana, Linda, R., dan Murkalina. (2012). Respon Pertumbuhan Setek Batang Sirih Merah (Piper crocatum Ruiz dan Pav) Setelah Direndam dalam Urine Sapi. Jurnal protobiont. 2(3): 157-160.

Mappanganro, N., Sengin E L., dan Baharuddin. (2010). Pertumbuhan dan Produksi Tanaman Stroberi Pada Berbagai Jenis dan Konsentrasi Pupuk Organik Cair dan Urine Sapi dengan Sistem Hidroponik Irigasi Tetes. Fakultas Pertanian, Universitas Hasanuddin.

Muswita. (2011). Pengaruh konsentrasi bawang merah (Allium cepa L.) terhadap pertumbuhan setek gaharu (Aquilaria malaccencis). Jurnal Penelitian Universitas Jambi Seri Sain. 13(1):15-20.

Nuraini dan Asgianingrum. (2017). Teknologi Pembuatan Bio-Urine dari Kencing Sapi yang Diperkaya dengan Pupuk Hayat. Balai Pengkajian Teknologi Pertanian (BPTP) Kepulauan Riau.

Oxlade, E. (2010). Plant Phisiology, the structure of plant explained. Viva Books Private Limited, United Kingdom. 
Perwitasari, B., Mustika T. Dan Catur W. (2012) Pengaruh media tanam dan nutrisi terhadap pertumbuhan dan hasil tanaman pakchoi (Brassica juncea L) dengan sistem hidroponik. J. Agrovigor. 5(1) :1-12.

Pratiwi, Y. I., Huda, N., \& Gunawan, B. (2017). Improvement Of Rating Of Stream Bud Chips Plant With Waste Liquid Of Cattle Farm. JHP17: Jurnal Hasil Penelitian. 2 (01).

Rukmana, R. (2017). Budidaya dan Pascapanen Bunga Potong Unggulan. Lily Publisher, Yogyakarta. 626 hal. ISBN: 978-979-29-6603-9

Setiaji, B.P. (2013). Respon Pemangkasan Pucuk dan Konsentrasi Pemberian Pupuk Organik Cair (Urin Sapi) terhadap Pertumbuhan dan Hasil Mentimu (Cucumis sativus L.) Varietas New Roberto. Tesis Pascasarjana UPN Veteran, Yogyakarta.

Supriyanto, Muslimin, dan Umar. (2014). Pengaruh Berbagai Dosis Pupuk Organik Cair Urine Sapi Terhadap Pertumbuhan Semai Jabon Merah (Anthocephalus macrohyllus. roxb.) Fakultas Kebutanan, Universitas Tadulako.

Tuhuteru, S., Hehanussa, M.L., dan Raharjo, S.H.T. (2012). Pertumbuhan dan perkembangan Anggrek Dendrobium anosmum pada media kultur in vitro dengan beberapa konsentrasi air kelapa. J.Agrologia. 1(1):1-12.

Wiraatmaja IR. I. Wayan. (2017). Zat Pengatur Tumbuh Auksin dan Cara Penggunaanya Dalam Bidang Pertanian. Program Studi Agroteknologi. Fakultas Pertanian. Universitas Udayana.

Yunita. (2011). "kandungan auksin dalam urine sapi". bttps:// docplayer.info/122324186Auksin-yang-terdapat-pada-urin-sapi-yaitu-auksin-a-auxentriollic-acid-auksin-b.btml. Diakses tanggal 27 Januari 2020.

Zhang, J., Chen, S., Liu, R., Jiang, J., Chen, F., Fang, W. (2013). Chrysanthemum Cutting Productivity and Rooting Ability are Improved by Grafting. The Scientific World Journal. Doi.org/10.1155/2013/286328. 